\title{
LDC Savings Rates and Debt Crises
}

\author{
HOMI J. KHARAS* \\ World Bank, Washington, DC \\ and \\ JIM LEVINSOHN \\ University of Michigan, Ann Arbor
}

\begin{abstract}
Summary. - Conventional wisdom holds that LDC debt problems reflect, in part, the switch of foreign financing towards commercial loans. With no adequate supervision over the use of these funds, international finance may not have improved the capacity to repay external debt. This paper tests two aspects of this proposition. First, have commercial loans been directed more towards consumption and less to investment than official loans? We find no evidence to suggest this has been true. Second, does an increase in the marginal propensity to invest out of foreign loans improve creditworthiness? Again, we find no supporting evidence. We do find, however, that raising the marginal rate of domestic saving out of income does improve creditworthiness. This provides justification for policy conditionality associated with foreign borrowing that goes beyond concern with the uses of individual loans.
\end{abstract}

\section{INTRODUCTION}

Conventional wisdom holds that less developed country (LDC) debt rescheduling problems reflect, in part, the failure of borrowers to invest their loans in productive activities with returns, evaluated at border prices, higher than the interest rate on their debt. This worry became particularly acute because of the rapid switch of external financing in the 1970 s away from official sources, mostly tied to closely supervised investment projects, towards commercial loans without such ties. Between 1975-78, one half of all eurocredits were destined for "banking and finance" and "general purpose," rather than for real fixed capital formation. The perceived danger was that such loans could be used to finance consumption and, by analogy with a firm that fails to invest borrowed funds, would lead to long-term insolvency. Indeed, most non-oil developing countries had lower average savings rates after 1973. ${ }^{1}$ Several policy statements sounded a warning that "international finance must serve to increase productive investment in debtor countries and to improve their capacity to repay their external debt." 2

The aim of this paper is to assess the empirical significance of these hypotheses. First, we ask whether high foreign borrowing has been associated with the fall in average savings rates. Next, we ask whether there has been any discernible difference in the marginal propensity to consume out of project and non-project foreign financing. Although we lack details on the classification of loans, we can safely assume that the period of the 1960 s and early 1970 s was characterized by a substantially larger proportion of project leading than the period of the mid- to late-1970s. The analysis of the relationship between savings and foreign exchange inflows follows the tradition of a substantial literature, e.g., Weisskopf (1972); Griffin (1970); Papanek (1972). A novel feature here is the explicit focus on structural change over time.

Second, we address the question of whether the structural coefficients of the consumption function have been important determinants of creditworthiness. That is, we attempt to establish the empirical significance of the hypothesis that more thrifty countries - those that invest more on the margin, both out of income and out of foreign resource inflows - are more creditworthy. Although such arguments have been asserted for many years, the empirical literature

* The World Bank does not accept responsibility for the views expressed herein which are those of the authors and should not be attributed to the World Bank or to its affiliated organizations. 
on the determinants of creditworthiness has completely ignored differences across countries and across time periods of important macroeconomic structural coefficients. ${ }^{3}$ As Kharas (1984) has argued before, there are sound theoretical reasons for inclusion of such coefficients. An empirical confirmation is also important because a substantial component of the policy conditionality associated with reschedulings is geared to the improvement of domestic savings rates and not to improvement in the traditional indicators of creditworthiness such as higher GDP or export growth. ${ }^{4}$

The remainder of this paper is organized as follows. In Section 2, we derive efficient estimators for the structural coefficients of interest. This involves estimating consumption functions for each of the 26 developing countries in our sample. The marginal propensities to consume out of both income and foreign borrowing are then included as independent variables in a probit analysis of the determinants of reschedulings in Section 3. Our findings indicate that marginal savings rates out of income are significant and have played a quantitatively important role in differentiating between country creditworthiness. A higher marginal propensity to invest out of foreign resource inflows seems to have played a minor quantitative and statistically insignificant role in determining creditworthiness. The policy implications of our analysis are expanded upon in the concluding Section 4. Our results provide cross-country empirical support for certain types of policy conditionality in packages designed to restore creditworthiness.

\section{CONSUMPTION FUNCTIONS}

The relationship between domestic savings and foreign resource inflows has generated considerable controversy. The empirical magnitude of the relationship and the policy implications that follow from a negative correlation between domestic savings and resource inflows from abroad are often disputed. ${ }^{5}$ For example, Griffin (1970) takes this as prima facie evidence that aid retards development. Others maintain that this is not a proper test of the effectiveness of aid. Even if there is a less than one-for-one increase in investment with an increase in foreign inflows, welfare would still be raised provided the real return on capital exceeded the real cost of borrowing. If there is a link between domestic savings rates and creditworthiness, however, there may be a need to reassess the impact of foreign inflow and to analyze whether different modalities of foreign financing have different macroeconomic effects.
The first stage of the analysis is to establish the impact of foreign inflows on domestic consumption and to test whether the marginal propensity to consume out of project-related foreign capital inflows is different from that out of non-project inflows. To do this, we estimate aggregate consumption functions for each of the 26 countries in our sample. Our procedure differs from the existing literature in two ways. First, we use only time-series, not cross-sectional, analysis. We avoid the bias that may arise due to the simultaneous determination of consumption and income by using instrumental variables. Second, we look for possible differences in the effects of alternative types of foreign financing. by testing for the structural stability of the relationship over time.

\section{(a) The model}

Consider the following simple model:

$$
\begin{aligned}
& P C=a_{0}+a_{1}(Y-T) \\
& B C=b_{0}+b_{1} T+b_{2} F I \\
& T=t_{0}+t_{1} Y-t_{2} F I \\
& T C=P C+B C
\end{aligned}
$$

where $P C, B C, T C$ are private, public and total consumption, respectively; $Y$ is a measure of income, $T$ is government net revenue and $F I$ is foreign inflows.

Private consumption is based upon disposable income. Government consumption is a function of net revenues and net foreign capital inflows into the country. Total net foreign capital inflows ${ }^{6}$ rather than public inflows alone are considered because this reflects total government borrowing from domestic and foreign sources. Government domestic borrowing in many instances forces the private sector to borrow offshore, or else is ultimately financed by a loss of foreign reserves. In both cases, net foreign inflows to the country increase even if official external borrowing does not. Government net revenue is also a function of income and net foreign inflows. The latter reflects the notion that public borrowing is often used to finance transfers to the private sector. Some governments may have weakened their tax collection as borrowing opportunities arose. In addition, borrowing has permitted a delay in adjustment to large relative price changes, reflected in growing public enterprise operating deficits and other forms of subsidies. 
Combining equations (1)-(4), we can derive a structural equation for total consumption:

$T C=c_{0}+c_{1} Y+c_{2} F I+u$

Equation (5) should not be estimated by ordinary least squares due to the simultaneous equation bias arising from the national accounts identity, $Y=T C+I+F I$. Accordingly, we use lagged values of $T C, I$, and $F I$ along with the contemporaneous value of $F I$ as instruments for $Y$. In this instance, then, two-stage least squares and instrumental variables estimation are identical. We give careful attention to deriving the correct standard errors of estimated parameters - a potential problem when the instrumental variables method is done in two steps.

In estimating equation (5), we treat foreign inflows as an exogenous variable. This is justified for two reasons. First, for many countries, foreign inflows are supply-determined. That is. credit rationing is likely to be pervasive. In the $1960 \mathrm{~s}$, this assumption seemed reasonable. Most foreign lending was by official creditors. or took the form of supplier credits or private direct investment. None of these would be responsive to short-term unanticipated changes in demand. Empirical results in Eaton and Gersovitz (1981) confirm this. During the mid-1970s, however, with the growth of syndicated lending, the existence of credit rationing was less pervasive. While some countries were still undoubtedly rationed (see Kharas and Shishido, 1984), others were not. Even for this latter group, however, we would argue that total foreign inflows can be properly treated as exogenous, even though the composition of capital flows, between long-term debt, short-term debt and reserve changes, may be endogenous. This follows in a long tradition of open-economy reduced-form equations (e.g., Kouri and Porter, 1974) in which the current account deficit is treated as an exogenous determinant of the components of capital inflows.

\section{(b) Data and results}

With these caveats, equation (5) was estimated using instrumental variables for 26 developing countries for the period 1961-81. The data were drawn from the World Bank's World Tables. They consist simply of the national income account series for each country. Foreign inflows are derived from national income data on exports and imports of goods and non-factor services, and on net factor income from abroad $(F I \equiv M-$ $X-\mathrm{NFI}$ ). All variables were expressed in per capita terms and deflated to limit heterosked- asticity. The consumption variable includes both private and public consumption. Measured income is defined as the sum of gross domestic output at current market prices plus net factor income from abroad. A Cochrane-Orcutt procedure was used to correct for serial correlation. whenever detected.

We then proceeded to test for any differences in the estimated marginal propensities to consume out of project $(P I)$ and non-project (NPI) foreign inflows. No direct test was feasible, because these are not independently observed variables; only the sum is observable from national accounts data. Details on the sources of foreign inflows, between private and official creditors, for example, are available, but there is no systematic macroeconomic information on the purpose of loans. Official loans, although primarily for projects, have recently been increasingly used for non-project purposes such as export promotion, budgetary support or balance of payments financing. Conversely, many private inflows have financed investment. Thus, the official/private distinction is not a good proxy for project/non-project comparisons. We can, however, make the assumption that non-project lending has increased substantially relative to project lending during the $1970 \mathrm{~s}$ as compared with the 1960s. This reflects both the growth of commercial eurocredits as a source of finance and the increasing attention given by official creditors to non-project financing. Given this assumption, we would expect differences between the marginal propensities to consume out of these types of foreign inflows to be reflected in a structural change over time in the estimated coefficient on aggregate foreign inflows. On the other hand, if foreign funds are fully fungible, then no such differences would be observed.

To see this formally, consider the following simple model where variables other than foreign inflows have been excluded for expositional purposes.

$$
T C_{t}=f_{1} P I_{t}+f_{2} \mathrm{NPI}_{\mathrm{f}}+v_{\mathrm{t}}
$$

$F I_{t} \equiv P I_{t}+\mathrm{NPI}_{t}$

We are interested in whether or not $f_{1}=f_{2}$. We only observe $F I$, however, not $P I$ or NPI. Consider the estimator, $f$, of the least squares coefficient obtained from a regression of consumption on total foreign inflows (equation (8)).

$T C_{t}=f F I_{t}+w_{t}$ 


$$
E(f)=f_{1} \cdot \frac{C(F I, P l)}{V(F I)}+f_{2} \frac{C(F I, \mathrm{NPI})}{V(F I)}
$$

where $C(F I, P l), C(F I, \mathrm{NPI})$ are the covariance of foreign inflows with its project and nonproject components, respectively, and $V(F I)$ is the variance of foreign inflows. Equation (9) shows that the estimated coefficient $f$ is simply a weighted average of the two underlying coefficients $f_{1}$ and $f_{2}$. Note that if $P I$ and NPI are independent, which does not seem too unreasonable, then the weights are simply the share that each variable contributes to the total variance of both. ${ }^{7}$ It is now easy to see that the assumption that non-project inflows were substantially more important during the 1970 s (and therefore have a large covariance with $F I$ ) implies that the weight of $f_{2}$ should be higher in this period. Thus, $E(f)$ for 1960-70 should be significantly different from $E(f)$ for $1970-80$ if $f_{1}$ is different from $f_{2}$. If, on the other hand, $f_{1}=f_{2}$, then the change in the weights has no impact on $f$ (indeed, using the sum of total foreign inflows, $F I$, is appropriate). We can, therefore, make inferences based on the detection of changes over time in $f$. In fact, $E(f)$ $70-80 \geqslant E(f)$ 60-70 implies $f_{2} \geqslant f_{1}$. (Of course, another possibility is that the true parameters, $f_{1}$ and $f_{2}$, are themselves changing over time in an unknown way. Then we cannot make any inferences about them.)

Structural change at alternative dates was examined using a Chow test. When a Chow test indicated a structural shift, the consumption function for that country was run using slope dummies for both the foreign inflows and the income variables. ${ }^{8}$ The dummies take a value of one after a certain date and zero before that date. Hence, we ran the following regression:

$$
\begin{aligned}
C_{t}= & a_{0}+a_{1} Y_{t}+a_{2} d . Y_{t}+a_{3} F I_{t}+ \\
& a_{4} d . F I_{t}+u_{t}
\end{aligned}
$$

The time at which we posit a shift was varied according to judgments based on knowledge of country experience. Where there was serial correlation, each sub-sample was transformed using the rho estimated for the whole sample. ${ }^{9}$

The results of the estimated consumption functions are shown in Table 1. The coefficients mostly have the right sign and are significant. In 12 countries, consumption is significantly raised by foreign inflows. The regressions are fairly stable over time. One-half of the sample, 13 countries, showed evidence of structural change. Of these, only one country (Colombia) showed a significant decline in the marginal propensity to consume out of foreign inflows during the later period covering the 1970s, while three (Brazil, Central African Republic and Tunisia) countries showed a significant increase. We conclude, therefore, that for most developing countries there is no strong evidence that the expansion of non-project lending in the 1970 s led to a structural change in the propensity to consume out of foreign inflows. There is, however, a strong association between higher borrowing and higher consumption throughout the period for most countries. It seems, therefore, that the fall in average savings rates that was observed during the 1970 s can be largely explained as a reflection of the expanding volume of foreign inflows rather than of the changing composition of such flows. The marginal savings rates do not seem to change.

\section{CREDITWORTHINESS ANALYSIS}

Following the analysis in Kharas (1984), we assume that creditworthiness problems arise when random shocks lead to a reduction of actual GNP below some critical level. The critical level of GNP, $Q^{c}$, is the level that would avoid longrun collapse in consumption and output if debt service were paid, given a stable relationship between consumption, income and net foreign inflows. ${ }^{10}$

$Q^{c}=g_{0}=g_{1} F l+g_{2} D$

where $D$ is debt outstanding.

The higher the level of net foreign inflows, and the lower the stock of debt, the lower is the critical output level. This follows from the fact that high net borrowing and low debt permit higher consumption and investment after debt service obligations have been met.

Creditworthiness problems are not actually observed. We do, however, observe reschedulings. Define a dependent variable, $y^{*}$, that when $y^{*}>0$, a rescheduling occurs and when $y^{*}<0$, it does not. We can relate $y^{*}$ to the ratio of critical to actual output.

$y^{*}=\frac{Q^{c}}{Q}-C+\zeta$

where $C$ is a constant. Assuming $\zeta$ to be normally distributed, (11) and (12) can be combined to get the probability of $y^{*}>0$ conditional on $Q$, $F I$, and $D$. 
Table 1. Estimated consumption functions

\begin{tabular}{|c|c|c|c|c|c|c|c|}
\hline Country & Constant & $Y$ & $F I$ & $D Y$ & DFI & $D W$ & Shift \\
\hline $\begin{array}{l}\text { Argentina } \\
1961-80\end{array}$ & $\begin{array}{l}-0.198 \\
(-0.90)\end{array}$ & $\begin{array}{l}0.862^{*} \\
(13.0)\end{array}$ & $\begin{array}{c}0.634 \\
(1.35)\end{array}$ & $\begin{array}{l}-0.048^{*} \\
(-3.08)\end{array}$ & $\begin{array}{l}-0.127 \\
(-0.96)\end{array}$ & $\begin{array}{l}1.21 \\
-\end{array}$ & $74 / 75$ \\
\hline $\begin{array}{l}\text { Bolivia } \\
1962-82\end{array}$ & $\begin{array}{c}0.173 \\
(0.960)\end{array}$ & $\begin{array}{l}0.742 * \\
(7.77)\end{array}$ & $\begin{array}{l}0.882^{*} \\
(3.13)\end{array}$ & $\begin{array}{c}0.023 \\
(0.988)\end{array}$ & $\begin{array}{l}-0.279 \\
(-0.713)\end{array}$ & $\begin{array}{c}1.31 \\
\text { (after CORC) }\end{array}$ & $75 / 76$ \\
\hline $\begin{array}{l}\text { Botswana } \\
1962-81\end{array}$ & $\begin{array}{l}0.020^{*} \\
(4.10)\end{array}$ & $\begin{array}{l}0.521^{*} \\
(11.8)\end{array}$ & $\begin{array}{r}0.233 \\
(1.73)\end{array}$ & - & 二 & $\begin{array}{c}1.45 \\
\text { (after CORC) }\end{array}$ & - \\
\hline $\begin{array}{l}\text { Brazil } \\
1962-81\end{array}$ & $\begin{array}{r}-0.195 \\
(-0.88)\end{array}$ & $\begin{array}{c}0.88^{*} \\
(7.43)\end{array}$ & $\begin{array}{c}-1.99 \\
(-1.71)\end{array}$ & $\begin{array}{l}-0.087 \\
(-1.36)\end{array}$ & $\begin{array}{l}3.27^{*} \\
(2.41)\end{array}$ & 1.75 & $75 / 76$ \\
\hline $\begin{array}{l}\text { C.A.R. } \\
\text { 1962-81 }\end{array}$ & $\begin{array}{c}3.27 \\
(0.480)\end{array}$ & $\begin{array}{l}0.831^{*} \\
(3.10)\end{array}$ & $\begin{array}{r}0.0609 \\
(0.557)\end{array}$ & $\begin{array}{c}-0.065^{*} \\
(2.47)\end{array}$ & $\begin{array}{l}0.847^{*} \\
(3.31)\end{array}$ & $\frac{1.18}{-}$ & $76 / 77$ \\
\hline $\begin{array}{l}\text { Colombia } \\
1961-82\end{array}$ & $\begin{array}{l}-0.532 \\
(-1.61)\end{array}$ & $\begin{array}{l}0.889^{*} \\
(14.5)\end{array}$ & $\begin{array}{l}0.989^{*} \\
(3.00)\end{array}$ & $\begin{array}{c}0.004 \\
(0.207)\end{array}$ & $\frac{-1.32^{*}}{(-3.48)}$ & $\stackrel{1.02}{-}$ & $73 / 74$ \\
\hline $\begin{array}{l}\text { Costa Rica } \\
1961-81\end{array}$ & $\begin{array}{c}0.693^{*} \\
(9.81)\end{array}$ & $\begin{array}{l}0.615^{*} \\
(28.4)\end{array}$ & $\begin{array}{l}0.623^{*} \\
(5.91)\end{array}$ & - & - & $\underline{1.28}$ & - \\
\hline $\begin{array}{l}\text { Ghana } \\
1961-82\end{array}$ & $\begin{array}{l}-0.101 \\
(-1.48)\end{array}$ & $\begin{array}{l}1.29^{*} \\
(4.30)\end{array}$ & $\begin{array}{c}0.760 \\
(1.39)\end{array}$ & - & - & 1.212 & - \\
\hline $\begin{array}{l}\text { Guyana } \\
1963-77\end{array}$ & $\begin{array}{l}-0.293 \\
(-1.22)\end{array}$ & $\begin{array}{c}1.19^{*} \\
(3.09)\end{array}$ & $\begin{array}{c}1.16 \\
(2.35)\end{array}$ & $\overline{-}$ & - & $\frac{1.64}{-}$ & - \\
\hline $\begin{array}{l}\text { India } \\
1961-82\end{array}$ & $\begin{array}{l}0.219^{*} \\
(4.39)\end{array}$ & $\begin{array}{l}0.758^{*} \\
(64.8)\end{array}$ & $\begin{array}{r}0.091 \\
(0.72)\end{array}$ & - & - & $\stackrel{1.04}{-}$ & $\underline{-}$ \\
\hline $\begin{array}{l}\text { Jamaica } \\
1963-82\end{array}$ & $\begin{array}{r}0.944 \\
(1.87)\end{array}$ & $\begin{array}{l}0.587^{*} \\
(5.12)\end{array}$ & $\begin{array}{r}0.295 \\
(0.59)\end{array}$ & $\begin{array}{l}0.0027 \\
(0.04)\end{array}$ & $\begin{array}{r}0.613 \\
(0.86)\end{array}$ & 1.83 & $72 / 73$ \\
\hline $\begin{array}{l}\text { Korea } \\
1962-82\end{array}$ & $\begin{array}{c}14.45^{*} \\
(13.18)\end{array}$ & $\begin{array}{l}0.63^{*} \\
(66.4)\end{array}$ & $\begin{array}{r}0.158 \\
(1.44)\end{array}$ & $=$ & $=$ & 1.13 & - \\
\hline $\begin{array}{l}\text { Malawi } \\
1961-81\end{array}$ & $\begin{array}{l}0.024^{*} \\
(8.58)\end{array}$ & $\begin{array}{l}0.476^{*} \\
(9.98)\end{array}$ & $\begin{array}{c}0.193 \\
(0.974)\end{array}$ & - & - & $\stackrel{1.55}{-}$ & - \\
\hline $\begin{array}{l}\text { Mexico } \\
1961-82\end{array}$ & $\begin{array}{r}0.171 \\
(1.17)\end{array}$ & $\begin{array}{l}0.788^{*} \\
(39.5)\end{array}$ & $\begin{array}{c}0.034 \\
(0.027)\end{array}$ & - & - & $\stackrel{1.20}{-}$ & - \\
\hline $\begin{array}{l}\text { Nicaragua } \\
1962-82\end{array}$ & $\begin{array}{l}0.513^{*} \\
(2.12)\end{array}$ & $\begin{array}{c}0.602^{*} \\
(0.855)\end{array}$ & $\begin{array}{r}0.334 \\
(1.93)\end{array}$ & $\begin{array}{l}-0.134^{*} \\
(-2.14)\end{array}$ & $\begin{array}{r}0.693 \\
(1 .+3)\end{array}$ & $\begin{array}{c}1.12 \\
\text { (after CORC) }\end{array}$ & $76 / 77$ \\
\hline $\begin{array}{l}\text { Nigeria } \\
1962-82\end{array}$ & $\begin{array}{l}0.4558 \\
(3.75)\end{array}$ & $\begin{array}{l}0.683^{*} \\
(14.7)\end{array}$ & $\begin{array}{l}0.572^{*} \\
(5.77)\end{array}$ & - & - & $\begin{array}{c}1.31 \\
-\end{array}$ & - \\
\hline $\begin{array}{l}\text { Pakistan } \\
1964-82\end{array}$ & $\begin{array}{c}0.018 \\
(0.432)\end{array}$ & $\begin{array}{l}0.829^{*} \\
(7.82)\end{array}$ & $\begin{array}{c}0.489 \\
(0.757)\end{array}$ & $\begin{array}{l}-0.009 \\
(-0.18)\end{array}$ & $\begin{array}{l}-0.547 \\
(-0.78)\end{array}$ & $\begin{array}{c}1.54 \\
\text { (after CORC) }\end{array}$ & $70 / 71$ \\
\hline $\begin{array}{l}\text { Paraguay } \\
1963-81\end{array}$ & $\begin{array}{c}10.56^{*} \\
(12.09)\end{array}$ & $\begin{array}{l}0.518^{*} \\
(17.0)\end{array}$ & $\begin{array}{l}0.763^{*} \\
(6.15)\end{array}$ & - & 1.46 & - & $=$ \\
\hline $\begin{array}{l}\text { Peru } \\
1961-81\end{array}$ & $\begin{array}{l}-5.37 \\
(-0.69)\end{array}$ & $\begin{array}{c}1.07^{*} \\
(2.78)\end{array}$ & $\begin{array}{r}0.873 \\
(1.22)\end{array}$ & $\begin{array}{l}0.063^{*} \\
(2.58)\end{array}$ & $\begin{array}{l}-0.610 \\
(-0.97)\end{array}$ & $\begin{array}{l}1.02 \\
-\end{array}$ & $69 / 70$ \\
\hline $\begin{array}{l}\text { Sierra Leone } \\
1963-81\end{array}$ & $\begin{array}{l}-0.043 \\
(-1.29)\end{array}$ & $\begin{array}{l}1.23^{*} \\
(4.46)\end{array}$ & $\begin{array}{r}1.36^{*} \\
(3.83)\end{array}$ & - & 二 & 1.44 & - \\
\hline $\begin{array}{l}\text { Sudan } \\
1961-82\end{array}$ & $\begin{array}{l}-0.006 \\
(-1.22)\end{array}$ & $\begin{array}{l}1.018^{*} \\
(9.87)\end{array}$ & $\begin{array}{r}1.19^{*} \\
(4.53)\end{array}$ & $\begin{array}{l}-0.068^{*} \\
(-2.78)\end{array}$ & $\begin{array}{l}-0.195 \\
(-0.50)\end{array}$ & $\begin{array}{l}1.74 \\
-\end{array}$ & $72 / 73$ \\
\hline $\begin{array}{l}\text { Thailand } \\
\text { 1962-82 }\end{array}$ & $\begin{array}{c}0.287^{*} \\
(4.94)\end{array}$ & $\begin{array}{l}0.717^{*} \\
(37.5)\end{array}$ & $\begin{array}{r}0.064 \\
(0.42)\end{array}$ & - & - & $\begin{array}{c}1.14 \\
\text { (after CORC) }\end{array}$ & $\overline{-}$ \\
\hline $\begin{array}{l}\text { Togo } \\
1963-82\end{array}$ & $\begin{array}{l}-5.00 \\
(-0.832)\end{array}$ & $\begin{array}{c}1.03^{*} \\
(5.47)\end{array}$ & $\begin{array}{l}0.363^{*} \\
(2.95)\end{array}$ & - & $=$ & 1.50 & 二 \\
\hline $\begin{array}{l}\text { Tunisia } \\
1964-82\end{array}$ & $\begin{array}{c}0.020 \\
(1.05)\end{array}$ & $\begin{array}{l}0.711^{*} \\
(6.27)\end{array}$ & $\begin{array}{l}-0.166 \\
(-0.31)\end{array}$ & $\begin{array}{l}-0.057^{*} \\
(-2.25)\end{array}$ & $\begin{array}{l}1.14^{*} \\
(2.12)\end{array}$ & $\begin{array}{c}1.89 \\
-\end{array}$ & $72 / 73$ \\
\hline $\begin{array}{l}\text { Zaire } \\
1961-80\end{array}$ & $\begin{array}{l}-0.015 \\
(-2.18)\end{array}$ & $\begin{array}{l}1.16^{*} \\
(6.35)\end{array}$ & $\begin{array}{c}0.241 \\
(0.686)\end{array}$ & $\begin{array}{c}-0.016 \\
(-0.541)\end{array}$ & $\begin{array}{c}-0.251 \\
(-0.678)\end{array}$ & $\frac{1.26}{-}$ & $66 / 67$ \\
\hline $\begin{array}{l}\text { Zambia } \\
1963-82\end{array}$ & $\begin{array}{c}0.028 \\
(1.58)\end{array}$ & $\begin{array}{l}0.518^{*} \\
(4.70)\end{array}$ & $\begin{array}{c}0.354 \\
(1.65)\end{array}$ & $\begin{array}{l}-0.059 \\
(-1.35)\end{array}$ & $\begin{array}{l}-0.135 \\
(-0.586)\end{array}$ & $\begin{array}{c}2.27 \\
\text { (after CORC) }\end{array}$ & $67 / 68$ \\
\hline
\end{tabular}

Note: consumption is the dependent variable: $t$-statistics are in parentheses.

*Significant at the $5 \%$ level. 


$$
\begin{gathered}
y^{*}=-C+g_{0} \cdot(1 / Q)-g_{1} \cdot(F / / Q)+ \\
g_{2} \cdot(D / Q)+\zeta
\end{gathered}
$$

Equation (13) is estimated in three ways. First, we assume that $C, g_{0}, g_{1}$ and $g_{2}$ are constant across countries and over time (Run 1). Next, we assume that there are country and time-specific effects in $C$, which are captured by the coefficients of the consumption functions estimated above. Thus we replace $C$ by $C^{l}+c_{0}+m p c y+$ mpcfi where $c_{0}$, mpcy and mpcfi are the consumption function constant term and long-run marginal propensities to consume out of income and foreign inflows, respectively (Run 2). Finally, we assume that the above parameters enter in a non-linear way (Run 3): $g_{0}$ is replaced by:

$g_{0}^{1}\left[c_{0} /\left(1-c_{1}\right)\right]$

and $g_{1}$ is replaced by

$g_{1}^{1}\left[\left(1-c_{2}\right) /\left(1-c_{1}\right)\right]$.

These transformations are derived in the Appendix.

\section{(a) Data and results}

Data on reschedulings were obtained from the World Bank's World Debt Tables, 1984. The dependent variable was assigned a value of one if a rescheduling occurred and zero otherwise. The independent variables, GDP and $F I$, are those already used in the consumption function regressions. Debt outstanding was taken from the World Debt Tables. The variables $c_{0}$ and mpcy and $m p c f i$ are derived from the regressions above.

Equation (13) was estimated with each country-year pair treated as a separate observation. The sample is as shown in Table 1. Thus, there were 251 total observations, of which 44 had reschedulings. Due to the binary nature of the dependent variable, we used a probit procedure. The coefficients are given in Table 2.

In the bench-mark Run 1, all the variables have the correct sign, but the coefficients on per capita output and net foreign inflows are insignificant. There appears to be no evidence that the richer developing countries are significantly more creditworthy. Nor does it appear that higher foreign borrowings lower the chance of rescheduling. High debt/output ratios emerge as the most significant determinants of reschedulings. This contrasts with earlier findings that all three variables are significant (Kharas, 1984). The difference is mostly attributable to the updating of the sample. In the period considered here, most of the rescheduling observations are on rich Latin American countries. Of particular interest here, however, is the significance of the coefficients on the consumption function introduced in Run 2. The coefficient on the marginal propensity to consume out of income has the correct sign and is significant. Countries that consume more on the margin are less creditworthy. The marginal propensity to consume out of foreign inflows, however, is insignificant. In addition, the absolute value of the coefficient is very small. There does not appear to be any support for the hypothesis that failure to use foreign inflows for investment purposes has been a factor in triggering debt crises."

Run 3 results corroborate these findings. In this run, the independent variables, output and net foreign inflows, are transformed into new variables using the estimated structural coefficients of the consumption functions. Although the first variable remains insignificant (the negative sign is due to the influence of $c_{0}$, the constant term from the consumption function), the coeffi-

Table 2. Determinants of rescheduling*

\begin{tabular}{lcccccccc}
\hline Run & $C$ & $1 / Q$ & $H / / Q$ & $D / Q$ & $c_{0}$ & $m p c y$ & $m p c f i$ & $\begin{array}{c}\text { Log } \\
\text { likelihood }\end{array}$ \\
\hline 1 & -1.52 & 3.86 & -1.59 & 0.382 & - & - & - & -145.7 \\
& $(-12.8)$ & $(0.367)$ & $(-1.48)$ & $(3.07)$ & - & - & - & \\
2 & 2.49 & 7.41 & -1.98 & 0.497 & -0.118 & 1.03 & 0.018 & -133.71 \\
& $(-6.83)$ & $(0.297)$ & $(-1.70)$ & $(3.47)$ & $(-2.61)$ & $(2.33)$ & $(-0.074)$ & \\
3 & 1.52 & $-0.032 \dagger$ & -0.48 & 0.239 & - & - & - & -145.6 \\
& $(13.94)$ & $(-0.12)$ & $(-2.17)$ & $(2.16)$ & - & - & - & \\
\hline
\end{tabular}

${ }^{*} t$-statistics in parentheses.

†Coefficient on transformed variable. 
cient on new foreign inflows, in combination with the income and inflows consumption propensities, becomes significant. These results suggest that concern with countries' savings rates out of income is indeed appropriate for lenders. Policy changes that improve domestic saving rates can be as important as organizing additional inflows, or improving GDP growth, in re-establishing creditworthiness. However, the use to which foreign funds are put, whether consumed or invested, does not appear to be important.

\section{CONCLUSION}

It has been argued that foreign inflows jeopardize creditworthiness both through the build-up of debt and through their negative impact on domestic saving. Some have suggested that the latter effect was reinforced in the 1970s due to the shift towards untied commercial sources of external funds. We have undertaken an empirical analysis of these hypotheses, covering 26 developing countries from 1961 to 1982 . We find in almost all cases that foreign borrowing does reduce average domestic saving rates. However, we find no evidence to suggest that shifts in sources and patterns of foreign financing have altered country behavior. It appears that from a macroeconomic view, foreign funds have been sufficiently fungible with domestic resources such that their impact on domestic investment and consumption has remained unchanged. regardless of whether the loans were tied to specific projects or not.

Also, we find strong empirical support for the proposition that raising marginal rates of saving out of income is significant in improving creditworthiness. The marginal propensity to consume out of foreign inflows, however, is not significant. Additional foreign lending, in and of itself, can improve creditworthiness in the short run, but worsens it in the long run as debt builds up. Only if foreign borrowing can help to achieve structural reform, through raising marginal saving rates, is its impact on creditworthiness substantial. This may occur even if average saving rates decline as a result of the foreign inflows. These findings support the usefulness of the kind of policy conditionality that has accompanied recent International Monetary Fund (IMF) and International Bank for Reconstruction and Development (IBRD) program loans to countries with debt servicing difficulties. For example, financial liberalization, control of inflation and maintenance of positive real interest rates, and reductions in the primary deficit of the public sector should all serve to raise long-run marginal saving rates.

\section{NOTES}

1. Middle-income oil-importing developing countries on average had savings rates of $21.5 \%$ in 1973 and $18.0 \%$ in 1981 .

2. Excerpt of speech by J. de Larosiere, Managing Director, IMF, delivered before the Economic and Social Council of the UN, Geneva, 3 July 1981.

3. For a review of the assertions and empirical evidence, see McDonald (1982).

4. For the most part, policy conditions have resulted in sharply lower investment and growth. The desired improvement in the trade balance has primarily been achieved through reduction in imports.

5. See, for example, Griffin (1970), Weisskopf (1982), Papanek (1972) and Heller (1975).

6. Total net foreign capital inflows are defined here as the sum of gross foreign capital inflows through borrowing, direct investment, or other capital flows, to both the public and private sectors, less total repayment of principal to foreigners. Given the accounting identities in the balance of payments, total foreign capital inflows is identical to the current account balance.
7. When the other independent variables are included in the model, the basic result that $f$ is a weighted average still holds but the weights are less easily interpreted in an intuitive fashion.

8. There is some pre-test bias with this approach. We are not, however, interested in estimating in an unbiased way precisely when the structural change occurred, but only if the coefficients are different between any two sub-samples. The bias, therefore, is in favor of detecting structural change.

\section{See Corsi, Pollock and Prakken (1982).}

10. See Appendix for a derivation of $Q^{c}$.

11. The figures in Table 2 should be treated with caution but not skepticism. The inclusion of estimated coefficients as independent variables gives rise to biased estimates. The quantitative impact of this bias, though, is likely to be very small given the high tstatistics on the estimated coefficients. This is a subject of further research by Levinsohn. 


\section{REFERENCES}

Chhibber, A., and H. Ghanem. "The impact of foreign inflows on consumption: An econometric analysis for six developing countries." CPD Discussion Paper, 198+25 (Washington. DC: World Bank. 1984).

Corsi. P., R. Pollock, and J. Prakken, "The Chow Test in the presence of serially correlated errors," in Chow and Corsi (Eds.). Evaluating the Reliability of Macroeconomic Models (New York: Wilcy, 1982).

Deaton. A., and M. Pesaran, "Testing non-tested nonlinear regression models," Economerrica, Vol. 42 (1978).

Eaton. J.. and M. Gersovitz, "Debt with potential repudiation: Theoretical and empirical analysis," Review of Economic Studies. Vol. 48, No. 152 (1981).

Griffin. K., "Foreign capital, domestic savings and economic development," Bulletin of Oxford University Institute of Economics and Statistics, Vol. 32. No. 2 (May 1970).

Heller, P.. "A model of fiscal behavior in developing countries: Aid, investment and taxation," American Economic Review, Vol. 65, No. 3 (June 1975).

Kharas, H. J., "The long-run creditworthiness of developing countries: Theory and practice." Quarterly Journal of Economics (August 1984).

Kharas, $\dot{H}$. J., and $H$. Shishido, "Credit rationing in international capital markets: An empirical analysis." CPD Discussion Paper. No, 1984-24 (October 1984)

Kouri. P. J. K., and M. G. Porter, "International capital flows and portfolio equilibrium." Journal of Political Economy, Vol. 82 (May/June 1974).

Maddala, G. S. Limited Dependent and Qualitative Variables in Econometrics (Cambridge: Cambridge University Press, 1983).

McDonald, D. C.. "Debr capacity and developing country borrowing: A survey of the literature," IMF Staff Paper, Vol. 29 (1982).

Papanek. G., "The effect of aid and other resource transfers on savings and growth in less developed countries." Economic Journal, No. 327 (September 1987).

Weisskopf. T. E. "The impact of foreign capital inflow on domestic savings in underdeveloped countries," Journal of Imternational Economics, Vol. 2, No. I (February 1972).

\section{APPENDIX}

Consider an economy where technology is Leontief, fixed-coefficients and labor is in surplus in the relevant range. The change in income is determined by the output/capital ratio, $b$, the previous year's level of in. vestment and the change in interest payments on external debt.

$$
\dot{Y}=b \dot{K}-r \dot{D}
$$

Investment, $K$, is given by the sum of domestic saving and foreign inflows.

$$
\begin{aligned}
\dot{K} & =Y-T C+\dot{D} \\
& =-c_{0}+\left(1-c_{1}\right) Y+\left(1-c_{2}\right) \dot{D}
\end{aligned}
$$

Foreign inflows are exogenously given by lenders. Assume gross inflows are exogenous and that amortization is a constant fraction of debt outstanding:

$$
\dot{D}=F I-\theta D
$$

\section{Rewriting}

$$
\begin{aligned}
& {\left[\begin{array}{l}
\dot{Y} \\
D
\end{array}\right]=\left[\begin{array}{cc}
b\left(1-c_{1}\right) & -r-b \theta\left(1-c_{2}\right) \\
0 & -\theta
\end{array}\right]\left[\begin{array}{c}
Y \\
D
\end{array}\right]+} \\
& {\left[\begin{array}{c}
b\left(1-c_{2}\right) \\
1
\end{array}\right] F I-\left[\begin{array}{c}
b c_{0} \\
0
\end{array}\right]}
\end{aligned}
$$

The general solution to the equation above is characterized by the two eiv pairs:

$$
\begin{aligned}
& \lambda_{1}=b\left(1-c_{1}\right), v_{1}=\left[\begin{array}{l}
1 \\
0
\end{array}\right]: \\
& \lambda_{2}=-\theta, v_{2}=\left[\begin{array}{c}
r+b 0\left(1-c_{2}\right) \\
b\left(1-c_{1}\right)+\theta
\end{array}\right]
\end{aligned}
$$

because the roots are real and of opposite signs, the solution is characterized by a saddle-point equilibrium. All points above the eigenvector $v_{2}$ lead to everdecreasing debt/income ratios. A critical income level can be defined, for each initial debt stock, such that above this level, domestic savings are sufficient to generate a growth path with falling debt-income in the long run.

$Y^{c}=\frac{r+b \theta\left(1-c_{2}\right)}{b(1-c) \theta} \cdot D-A . F I+\frac{c_{11}}{1-c_{1}}$

where $A$ is a constant that depends on $\left(1-c_{1}\right)$ and $\left(1-c_{2}\right)$. 